\title{
Kritik Sosial dan Nilai Moral dalam Novel "Negeri di Ujung Tanduk" Karya Tere Liye
}

\author{
Alvika Candra Puspita ${ }^{a 1}$, Sarwiji Suwandi ${ }^{\text {a2 }}$, dan Sri Hastutia3 \\ ${ }^{a}$ Universitas Sebelas Maret Surakarta \\ ${ }^{1}$ alvikacandra28@gmail.com, ${ }^{2}$ sarwijiswan@staff.uns.ac.id, ${ }^{3}$ hastuti2005@gmail.com
}

\section{Article info}

Article history:

Received: 15-09-2017

Revised : 10-10-2018

Accepted: 09-12-2018
Keywords:

family

moral values,

novel

social criticism

Tere Liye

\section{A B S T R A C T}

Social criticism and moral values can be found in many literary works, especially novels. The objectives of this research are to describe: (1) social criticism and (2) moral values within the "Negeri di Ujung Tanduk" novel by Tere Liye. This research used a qualitative method as a guideline to analyze documents containing information in the novel. To collect data, a purposive sampling technique and document analysis were used considerably. Data analysis techniques used interactive analysis techniques consisting of data reduction, data presentation, as well as withdrawal and testing conclusions. The outcomes of this research include (1) the social criticism within the "Negeri di Ujung Tanduk" novel such as (a) crime, (b) family disorganisation, (c) social norm violation, dan (d) bureaucracy; and (2) Moral values within the "Negeri di Ujung Tanduk" novel such as (a) individual moral values, (b) social moral values, and (c) religious moral values.

Kritik sosial dan nilai moral banyak terdapat dalam karya sastra khususnya novel. Tujuan penelitian ini adalah untuk mendeskripsikan: (1) kritik sosial dan (2) nilai moral dalam novel "Negeri di Ujung Tanduk" karya Tere Liye. Penelitian ini termasuk penelitian kualitatif yang menganalisis data berupa dokumen dengan objek kajian novel "Negeri di Ujung Tanduk" karyaTere Liye. Teknik pengambilan subjek penelitian dengan purposive sampling. Teknik pengumpulan data berupa analisis dokumen. Teknik analisis data menggunakan teknik analisis interaktif yang terdiri dari reduksi data, penyajian data, serta penarikan dan pengujian simpulan. Hasil penelitian ini dikemukakan sebagai berikut: (1) Kritik sosial yang terdapat dalam novel "Negeri di Ujung Tanduk", meliputi (a) kejahatan, (b) disorganisasi keluarga, (c) pelanggaran terhadap norma-norma masyarakat, (d) birokrasi, dan (2) Nilai moral yang terdapat dalam novel "Negeri di Ujung Tanduk", meliputi, (a) nilai moral individu, (b) nilai moral sosial, dan (c) nilai moral religius.

Copyright @ 2018 Institut Agama Islam Negeri Syekh Nurjati Cirebon. All rights reserved.

\section{PENDAHULUAN}

Kritik sosial dan nilai moral banyak ditemukan dalam karya sastra. Karya sastra merupakan bentuk dan cipta seni yang menggunakan manusia sebagai objek dan bahasa sebagai medianya. Karya sastra menuangkan pendapat, gagasan, ide, pengetahuan, dan perasaan penciptanya mengenai hakikat kehidupan yang disampaikan dengan komunikatif, indah, dan emosional. Karya sastra diciptakan untuk dinikmati, dipahami, dan dimanfaatkan oleh masyarakat. Menurut Jusriani (2015), karya sastra merupakan fenomena kemanusian yang kompleks, ada peristiwa suka, duka dan berbagai peristiwa hidup lainnya. Semua Itu merupakan hasil ciptaan manusia yang ditujukkan untuk manusia, 
berisikan tentang kehidupan manusia, memberikan gambaran kehidupan dengan segala aspek kehidupannya. bahwa karya sastra merupakan hasil kreativitas pengarang yang menggunakan manusia dan segala macam segi kehidupannya sebagai objek kajiannya.

Sebuah karya sastra yang baik mengandung makna dan memberikan kesan positif bagi pembacanya. Ratna (2009) menyatakan bahwa sebuah karya sastra bisa diteliti melalui berbagai pendekatan yang berkaitan dengan segala hal yang menyangkut kehidupan manusia atau masyarakatnya. Dengan demikian, karya sastra bukan sekadar sebuah karya imajinasi yang dapat dinikmati, tetapi juga bisa dipelajari dari berbagai aspek kehidupan seperti linguistik, sosiologi, psikologi, moral, agama, dan tingkah laku manusia pada suatu masa. Karya sastra pada umunya berisi tentang permasalahan kehidupan manusia. Permasalahan tersebut dapat berupa segala sesuatu yang terjadi dalam diri pengarang maupun terinspirasi dari orang lain. Karya sastra yang banyak ditemukan kemiripan dengan kehidupan nyata adalah novel.

Novel merupakan karya rekaan yang menggambarkan kehidupan dalam satu masyarakat tertentu seperti adat istiadat, aturan, serta budaya. Novel memberikan gambaran aspek-aspek kehidupan yang dikemas dalam gaya bahasa yang mudah dimengerti (Mulyaningsih, 2015). dan dituangkan ke dalam bentuk tulisan. Dalam novel dapat ditemukan nilai-nilai kemanusiaan yang dapat dijadikan sebagai alat pembelajaran bagi pembacanya. Salah satu pengarang yang menggunakan gaya bahasa yang khas adalah Tere Liye. Tere Liye sangat produktif dan dikenal karena gaya khasnya dalam menyampaikan sebuah kisah dengan bahasa yang mudah dipahami sehingga dapat diterima oleh masyarakat.

Novel yang baik adalah novel yang pengarangnya mampu mengangkat masalahmasalah sosial masyarakat ke dalam cerita yang menarik sehingga pembaca dapat mengetahui kritik sosial yang dapat diambil. Salah satu novel yang mampu mengangkat tentang kritik sosial di kalangan masyarakat adalah novel Negeri di Ujung Tanduk karya Tere Liye (2016). Novel ini mempunyai daya tarik sendiri yang berbeda dari novel lain. Novel ini mengangkat kisah yang memiliki kemiripan dengan realita sosial yang terjadi di zaman sekarang dan jarang disinggung dalam sastra Indonesia. Novel Negeri di Ujung Tanduk mengangkat realitas sosial yang mengandung banyak kontroversi yang berhubungan dengan kritik sosial. Dengan adanya peristiwa-peristiwa yang terjadi dalam novel ini, terdapat beragam nilai moral yang sangat bermanfaat. Oleh karena itu, peneliti 


\section{Indonesian Language Education and Literature e-ISSN: 2502-2261 \\ http://www.syekhnurjati.ac.id/jurnal/index.php/jeill/ \\ Vol. 4, No. 1, Desember 2018, 11 - 21}

tertarik untuk meneliti kritik sosial dan nilai moral yang terkandung pada fenomena tersebut menggunakan pendekatan sosiologi sastra.

Sosiologi sastra merupakan kajian yang membahas tentang suatu sastra sebagai cerminan dari kehidupan masyarakat, sehingga kehidupan sosial akan memicu lahirnya sebuah karya sastra. Dengan berbagai macam masalah sosial di kehidupan masyarakat, kritik sosial pun muncul dari kalangan pengarang dan dituangkan dalam karyanya, sehingga pendekatan sosiologi sastra sangat tepat untuk menganalisis kritik sosial karena sama-sama menyinggung pada hubungan terhadap kehidupan sosial. Kejadian-kejadian yang terjadi di masyarakat terdiri atas berbagai macam permasalahan. Endraswara (2011) mengatakan bahwa sosiologi sastra merupakan penelitian yang terfokus pada masalah manusia, karena sastra sering mengungkapkan perjuangan umat manusia dalam menentukan masa depannya, berdasarkan imajinasi, perasaan, dan intuisi.

Dalam menciptakan karya sastra, seorang pengarang hendaknya mampu menyiratkan nilai-nilai yang ingin disuguhkan kepada pembaca. Banyak nilai yang perlu disimak dalam sebuah karya sastra. Kritik sosial dan nilai moral merupakan sesuatu yang saling berkesinambungan. Dengan menguak kritik sosial, kita dapat mendistribusikan nilai moral yang terkandung sehingga dapat digunakan sebagai pembelajaran hidup.

Kata "novel" berasal dari "novellus" yang berarti baru. Jadi, sebenarnya memang novel adalah bentuk karya sastra cerita fiksi yang paling baru. Goldman mendefinisikan novel sebagai cerita yang terdegradasi akan nilai-nilai otentik yang dilakukan oleh hero yang problematik dalam sebuah dunia yang juga terdegradasi (dalam Faruk, 2010). Hal tersebut selaras dengan apa yang dipaparkan Semi (2012) yang menyatakan bahwa novel mengungkapkan suatu konsentrasi pada suatu saat tegangan dan pemusatan kehidupan yang tegas. Novel merupakan karya fiksi yang mengungkapkan aspek kehidupan manusia yang lebih mendalam dan disajikan dengan halus. Selanjutnya, Esten (2013) berpendapat bahwa novel merupakan pengungkapan fragmen kehidupan manusia (dalam jangka yang lebih panjang) di mana terjadi konflik-konflik yang akhirnya menyebabkan terjadinya perubahan jalan hidup antara para pelaku.

Novel tercipta berdasarkan realitas sosial yang ada dalam masyarakat, seperti halnya sosiologi sastra yang sama-sama berhubungan dengan masyarakat. Sosiologi sastra adalah ilmu yang membicarakan hubungan timbal balik antara sastrawan, sastra, dan masyarakat. Untuk mendekati karya sastra perlu menggunakan suatu pendekatan sosiokultural. Pendekatan ini menyimpulkan bahwa karya sastra tidak dapat dipahami secara selengkap- 


\section{Indonesian Language Education and Literature \\ e-ISSN: 2502-2261 \\ http://www.syekhnurjati.ac.id/jurnal/index.php/jeill/ \\ Vol. 4, No. 1, Desember 2018, 11 - 21}

lengkapnya dan tidak bisa dipisahkan dari lingkungan atau peradaban yang telah menghasilkannya (Wiyatmi, 2009).

Wellek dan Werren (2014) mengemukakan menjadi tiga paradigma pendekatan dalam sosiologi sastra, yaitu: (1) sosiologi pengarang, yaitu pendekatan yang menelaah mengenai latar belakang sosial, status sosial pengarang, dan ideologi pengarang yang terlihat dari berbagai kegiatan pengarang di luar karya sastra; (2) sosiologi karya yaitu pendekatan yang menelaah isi karya satra, tujuan, serta hal-hal yang tersirat dalam karya sastra itu sendiri dan yang berkaitan dengan masalah sosial; dan (3) sosiologi pembaca dan dampak sosial karya sastra yaitu pendekatan yang menelaah mengenai sejauh mana sastra ditentukan atau tergantung dari latar sosial, perubahan dan perkembangan sosial.

Secara sederhana, kritik sosial merupakan salah satu bentuk kepekaan sosial. Nurgiyantoro (2013), berpendapat bahwa sastra yang mengandung pesan kritik atau disebut dengan sastra kritik lahir di tengah-tengah masyarakat jika terjadi hal-hal yang kurang beres dalam kehidupan sosial dan masyarakat. Secara sederhana, kritik sosial merupakan salah satu bentuk kepekaan sosial. Oleh karena itu kritik sosial mencakup berbagai segi kehidupan baik politik, ekonomi, sosial, dan budaya. Kellner berpendapat mengenai kritik sosial. Soekanto (2013) mengemukakan kepincangan-kepincangan yang dianggap sebagai problema sosial oleh masyarakat antara lain: (1) kemiskinan, (2) kejahatan, (3) disorganisasi keluarga, (4) masalah generasi muda dalam masyarakat modern, (5) peperangan, (6) pelanggaran terhadap norma-norma masyarakat, (7) masalah kependudukan, (8) masalah lingkungan hidup, dan (9) birokrasi.

Untuk menghindari masalah-masalah sosial tersebut maka perlu ditanamkan nilai moral pada tiap-tiap individu. Nurgiyantoro (2013) memaparkan bahwa secara garis besar, jenis ajaran moral dapat dibedakan menjadi tiga macam antara lain: (1) moral yang mencangkup manusia dengan dirinya sendiri; (2) moral yang mencakup hubungan manusia dengan manusia lain dalam lingkup sosial temasuk hubungannya dengan lingkungan alam; dan (3) moral yang mencakup hubungan manusia dengan Tuhannya. Dari pendapat ini, nilai moral terkait dengan dimensi manusia sebagai individu, makhluk sosial, dan makhluk religius.

Suseno (2010) memaparkan bahwa terdapat sikap-sikap yang dianggap mendasari kepribadian (manusia sebagai individu) yang kuat berhubungan dengan moral, diantaranya: (1) kejujuran, (2) nilai-nilai otentik, (3) kesediaan untuk bertanggung jawab, (4) kemandirian moral, (5) keberanian moral, (6) kerendahan hati, (7) realitas dan kritis. 
Schiller (dalam Wibowo, 2013) menyatakan bahwa sastra bisa menjadi semacam permainan menyeimbangkan segenap kemampuan mental manusia, berhubung dengan adanya kelebihan energi yang disalurkan. Dengan kesusastraan, seseorang diasah kreativitas, perasaan, kepekaan, dan sensitivitas kemanusiaanya, sehingga terhindar dari tindakan-tindakan destruktif, sempit, kerdil, dan picik.

\section{METODE}

Penelitian ini adalah penelitian kualitatif yang menganalisis data berupa dokumen dengan objek kajian novel Negeri di Ujung Tanduk karya Tere Liye. Sumber data novel Negeri di Ujung Tanduk, RPP dan Silabus kelas XII semester genap, hasil wawancara guru dan siswa. Teknik pengambilan subjek penelitian dengan purposive sampling. Teknik pengumpulan data berupa analisis dokumen dan wawancara. Uji validitas data menggunakan trianggulasi sumber data. Teknik analisis data menggunakan teknik analisis interaktif yang terdiri atas reduksi data, penyajian data, serta penarikan dan pengujian simpulan.

\section{HASIL DAN PEMBAHASAN}

\section{Kritik Sosial dalam Novel Negeri di Ujung Tanduk Karya Tere Liye}

Kejahatan. Kejahatan yang ditemukan dalam novel ini berupa tindak kejahatan cyber crime, korupsi, mafia hukum, pengancaman, perekayasaan, dan tindak suap.

Cyber crime merupakan tindak kejahatan yang dilakukan oleh orang-orang yang menguasai bidang teknologi informatika dengan suatu tujuan tertentu. Dalam novel Negeri di Ujung Tanduk ditemukan kritik terhadap tindak kejahatan cyber crime oleh Kris, salah satu karyawan Thomas yang dulu pernah meretas salah satu pusat data perusahaan retailer Singapura dan Shinpei yang menghilangkan namanya di seluruh jaringan internet, menyebabkan kejahatan-kejahatan yang ia lakukan tidak ditemukan dalam jejaring sosial.

Korupsi merupakan salah satu tindak kejahatan keuangan yang biasanya dilakukan oleh para pejabat atau pengusaha. Terdapat tindak korupsi yang tercermin dalam novel Negeri di Ujung Tanduk. Kasus korupsi tersebut dilakukan oleh pihak kepolisian melalui pemasukan uang dari penerbitan surat izin mengemudi, pengadaan barang atau proyek, koperasi kepolisian, dan sebagainya. Selain itu lima anggota DPR, petinggi partai, melakukan tidak korupsi Proyek Pembangunan Pusat Olahraga Nasional. 

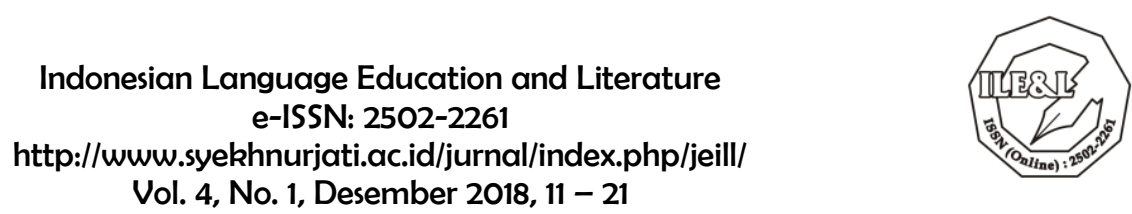

Mafia hukum melibatkan banyak institusi mulai dari penegak hukum, birokrat, legislatif, pengusaha, dan siapa pun yang merasa berkepentingan dengan hukum. Dalam novel ini terdapat beberapa tindak kejahatan yang dilakukan oleh para mafia hukum. Pertama, penyelundupan seratus kilogram bubuk heroin dan sekarung geranat ke sebuah kapal pesiar. Kedua, penyelesaikan berbagai masalah hukum kepada orang yang menyerahkan upeti. Ketiga, keterlibatan intrik politik atas perekayasaan tuduhan korupsi agar menggagalkan pemilihan presiden partai. Keempat, penghianatan kepada para anggota mafia hukum itu sendiri. Kelima, penyerangan konvoi pemindahan tahanan yang dilakukan KPK.

Pengancaman merupakan tindakan yang dapat memengaruhi seseorang dalam mengambil suatu keputusan. Tindak pengancaman dilakukan Shinpei kepada Thomas agar tidak terlambat ketika menemuinya. Jika hal itu terjadi dia akan membunuh Tante dan Opanya. Shinpei juga mengancam Thomas agar tidak membawa orang lain untuk menemuinya. Tidak hanya itu, pengancaman dilakukan anak buah Shinpei yang menodongkan moncong pistol di pelipis Thomas agar ia tidak bertindak macam-macam. Shinpei pun mengancam Om Liem agar mengatakan di mana barang bukti yang ia simpan, kalau tidak Shinpei akan menembak paha kiri keponakannya.

Perekayasaan adalah tindakan yang sangat merugikan bagi masyarakat. Kejahatan perekayasaan dalam novel Negeri di Ujung Tanduk meliputi penyelundupan seratus kilogram bubuk heroin dan sekarung senjata api dalam kapal pesiar; penangkapan kandidat presiden partai dengan tuduhan korupsi mega proyek tunnel raksasa ibu kota; perekayasaan kepolisian dalam menjalankan tugas, sel penjara yang hanya dijadikan formalitas karena dibuat sedemikian rupa nyaman dan aktivitas bisnis tetap bisa dijalankan; jaksa meringankan hukuman, sehingga tidak sesuai dengan undang-undang yang ditetakan; dan perekayasaan dibuat Thomas untuk membalas musuh-musuh keluarganya. Hanyalah omong kosong apabila ingin menegakkan hukum di negeri ini jika masih banyak tindak perekayasaan yang mempermainkan masyarakatnya.

Kejahatan tindak suap pada novel ini menjelaskan tentang perbuatan suap yang dilakukan oleh Thomas untuk mengumpulkan simpati dari para wartawan dan redaktur dari berbagai media masa serta pengamat politik. Selain itu Thomas juga melakukan kejahatan tindak suap saat ia dan Maryam ditahan di penjara. Meskipun dalam keadaan terdesak, tindak suap bukanlah suatu pemecahan masalah yang baik untuk dilakukan, karena tindak suap bertentangan, baik dengan hukum atau norma sosial. 
Indonesian Language Education and Literature

e-ISSN: 2502-2261

http://www.syekhnurjati.ac.id/jurnal/index.php/jeill/

Vol. 4, No. 1, Desember 2018, 11 - 21

Disorganisasi Keluarga. Disorganisasi keluarga dalam dalam novel Negeri di Ujung Tanduk tercermin dari tokoh Thomas dan JD yang sudah tidak memiliki kedua orangtua serta Om Liem sebagai paman Thomas yang memiliki banyak catatan kasus kejahatan sehingga tidak dapat memenuhi kewajibannya kepada keluarga.

Pelanggaran terhadap Norma-Norma di Masyarakat. Pelanggaran terhadap norma-norma di masyarakat dalam novel Negeri di Ujung Tanduk juga ditunjukkan dengan permasalahan yang diceritakan dalam novel ini. Pelanggara tersebut berupa pesta seks, pelacuran, hubungan di luar nikah, homoseksual, pernikahan sesama jenis, dan perjudian.

Birokrasi. Sedangkan birokrasi yang terdapat dalam novel ini lebih menekankan pada penyalahgunaan kekuasaan atau wewenang. Terdapat empat penyalahgunaan kekuasaan atau pejabat birokrasi, di mana kasus seperti ini biasanya dilakukan oleh pemimpin atau pejabat elit kepada bawahannya yang tidak lagi membedakan yang mana kepentingan umum dan mana kepentingan pribadi. Terdapat pula masalah birokrasi berupa pungutan liar, di mana para pelayan masyarakat mengambil keuntungan yang tidak seharusnya dilakukan. Selain itu digambarkan pula pemalsuan identitas yang secara administratif membohongi banyak pihak.

\section{Nilai Moral dalam Novel Negeri di Ujung Tanduk Karya Tere Liye}

Nilai Moral Individu. Pada Novel Negeri di Ujung Tanduk karya Tere Liye ditemukan beberapa nilai moral individu dari beberapa tokoh.

Novel Negeri di Ujung Tanduk mengandung gambaran-gambaran terkait sikap jujur. Digambarkan dalam beberapa tokoh yang memiliki sikap jujur seperti Maryam, Opa, dan Kadek. Selain itu, JD juga memiliki kepribadian yang jujur karena dia memiliki citacita untuk menegakkan hukum di negeri ini. Hanya orang yang jujurlah yang berani memiliki cita-cita tersebut. JD juga selalu terbuka tentang keuangan dinas yang tidak pernah ia gunakan untuk perjalanan pribadi. Tidak seperti pejabat-pejabat pada zaman sekarang yang kurang terbuka dan sering melakukan tindak kejahatan korupsi. Dalam kepolisian pun masih banyak polisi-polisi yang jujur ingin memegang janji setia sebagai seorang polisi. Banyak penegak hukum yang justru melanggar hukum seperti yang tergambar dalam novel ini.

Sikap tanggung jawab diperlihatkan oleh beberapa tokoh seperti Kadek yang merasa sebagai kapten kapal, sehingga apa yang terjadi di kapalnya dia merasa bertanggung jawab penuh. Lee memiliki sikap tanggung jawab karena dia pernah berjanji akan menuruti permintaan apa pun dari Thomas. Benar, ia menepati janjinya dan selalu 


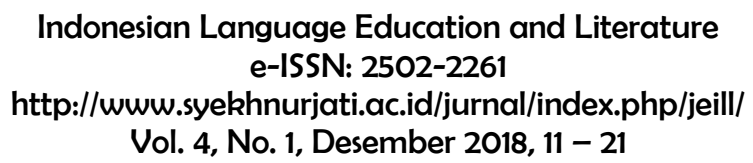

membantu Thomas ketika dalam masalah. Salah satunya membantu Thomas kembali ke Jakarta dengan menyediakan pesawat pribadinya dan mengurus surat-surat perjalanannya. Lima komisioner KPK yang menepati janjinya untuk menangkap lima anggota DPR yang melakukan tindak korupsi. Hal itu merupakan sikap tanggung jawab KPK untuk memberantas korupsi di negeri ini.

Sikap mandiri juga terdapat dalam novel Negeri di Ujung Tanduk. Hal ini tercermin dari beberapa sikap tokoh yaitu Maryam yang mengejar jadwal Thomas sampai ke Hong Kong demi memenuhi tugas yang diberikan atasannya. Ia juga tidak mudah menyerah, kapok dan trauma terhadap suatu kejadian. Selanjutnya para siswa yang dididik di asrama mempunyai sikap mandiri karena sudah dibiasakan untuk mengurus diri sendiri, termasuk kebutuhan sehari-hari.

Keberanian dalam menghadapi bahaya dan masalah dalam novel Negeri di Ujung Tanduk. yaitu Thomas yang membuka perusahaan konsultan politik meskipun mengetahui risiko yang akan dihadapi. Dengan berani Thomas melawan para mafia hukum yang selalu berusaha untuk menggagalkan klien politiknya mengikuti konvensi pemilihan presiden partai. Thomas juga merupakan seorang petarung yang memiliki keberanian yang besar, karena seorang petarung selalu selalu siap dan berani menghadapi lawan-lawannya dengan teknik dan kekuatan yang dimiliki.

Novel Negeri di Ujung Tanduk menampilkan beberapa tokoh yang memiliki sikap rendah hati, yaitu Thomas yang menghargai kerja keras Maryam untuk mengejar jadwalnya sampai ke Makau dan memujinya sebagai wartawan terbaik karena ditugaskan untuk mewawancarai Thomas yang dikenal dengan orang yang tertutup. Kerendahhatian Thomas juga tercermin saat ia berterima kasih kepada Lee yang telah membantunya meskipun Thomas pernah mengalahkan Lee saat pertarungan di Makau. Maryam juga memiliki kerendahan hati, tercermin ketika Thomas memintanya bergabung dengan Opa dan Kadek di meja makan ia menyetujui untuk menghargainya meski masih memiliki beberapa daftar pertanyaan.

Novel Negeri di Ujung Tanduk mencerminkan beberapa kepribadian tokoh yang memiliki sikap realistik dan kritis, yaitu Thomas yang membuka perusahaan konsultan politik dengan konsep kemasan paling menarik, bersih, muda, dan sederhana. Berbagai ide yang muncul meskipun dalam keadaan terdesak sekalipun. Thomas memiliki kemampuan berkomunikasi yang baik, apalagi kemampuan persuasif yang dapat memengaruhi para pendengarnya. JD memiliki pemikiran yang kritis dengan melihat masalah-masalah sosial 
yang terjadi di sekitarnya maka ia memiliki cita-cita untuk menegakkan hukum di negara ini. Ia sadar, dengan menegakkan hukum banyak masalah-masalah yang akan terselesaikan. Meggie juga memiliki sikap kreatif karena dia selalu berpikir dua langkah ke depan. Tugas-tugas yang diberikan Thomas kepadanya selalu selesai dengan baik. Sikap realistik dan kritis sangat dibutuhkan dalam berbagai pekerjaan, dengan memiliki sikap ini kita dapat memecahkan berbagai permasalahan dan akan muncul ide-ide yang dapat bermanfaat baik bagi diri sendiri maupun bagi orang banyak.

Nilai Moral Sosial. Nilai moral sosial adalah nilai yang mencakup hubungan manusia dengan manusia lain dalam lingkup sosial termasuk hubungannya dengan lingkungan alam. Nilai moral sosial dapat berupa peduli sosial, peduli lingkungan, cinta kasih, rela berkorban, dan semua yang berhubungan dengan etiket sosial. Dalam novel Negeri di Ujung Tanduk ini ditemukan nilai moral sosial yang menonjol yaitu mengenai peduli sosial. Peduli sosial tercermin dalam beberapa kutipan di samping seperti saling membantu antara Thomas, Kadek, Opa, dan Maryam saat meloloskan diri dari satuan SAR Hong Kong. Lee juga membantu mereka dalam meloloskan diri dan membawa mereka dengan pesawat pribadinya untuk kembali ke Jakarta. Serta Thomas yang menyelamatkan nyawa Om Liem saat kasus Bank Semesta. Selanjutnya peduli sosial juga tercermin ketika terjadi kebakaran di rumah Thomas. Para tetangga saling membantu untuk menyelamatkan apa dan siapa pun yang ada di dalamnya. Hal itu karena Mama Thomas yang terkenal amat peduli dengan sekitar. Selain itu, kepedulian Opa kepada Chai Ten ketika jatuh sakit saat berada di kapal. Opa selalu merawat dan menemaninya. Berbagi apapun yang ia punya. JD juga senantiasa memberi nasihat kepada anak-anaknya agar selalu peduli dan menolong sesama. Tercermin dari puisi yang ditulis anak perempuan JD yang berisi pesan-pesan untuk anak-anaknya. Rasa kepedulian dan cinta kasih bukan hanya untuk anggota keluarga saja, tetapi kepedulian dapat kita berikan kepada semua orang. Peduli kepada sesama sangatlah penting dan dibutuhkan oleh semua orang. Dengan adanya rasa peduli terhadap sesama akan membawa kedamaian dan kenyamanan bagi setiap orang.

Nilai Moral Religius. Nilai moral religius adalah segala sesuatu tentang sikap yang berhubungan dengan Tuhan atau kepercayaan kepada Tuhan. Nilai moral religius menjunjung tinggi sifat-sifat manusiawi, hati nurani yang dalam, serta kebebasan pribadi yang dimiliki manusia. Novel Negeri di Ujung Tanduk memiliki kandungan nilai moral religius berupa rasa syukur Tante Liem ketika mengetahui bahwa Thomas selamat, serta rasa syukur Thomas karena selamat setelah kejadian kejar-kejaran dengan pasukan khusus 
dan akhirnya menghantam loket pintu tol. Berbakti kepada orangtua juga salah satu nilai moral sosial yang patut dicontoh, karena dalam agama selalu diajarkan agar patuh kepada orangtua. Begitu juga yang dilakukan oleh anak-anak JD yang senantiasa membantu dan mematuhi apa yang diperintahkan ibunya. Selain itu, senantiasa berdoa mencerminkan nilai moral religius seperti apa yang disarankan Thomas kepada anak-anak JD agar senantiasa mendoakan ayahnya.

\section{SIMPULAN}

Berdasarkan pembahasan dan hasil analisis data, dapat diambil simpulan sebagai berikut. Pertama, kritik sosial dalam novel Negeri di Ujung Tanduk yaitu: (a) kejahatan (cyber crime, korupsi, mafia hukum, pengancaman, perekayasaan, dan tindak suap); (b) disorganisasi keluarga yang tidak dapat memenuhi kewajibannya terhadap keluarga; (c) pelanggaran terhadap norma-norma masyarakat berupa pesta seks, pelacuran, hubungan di luar nikah, homoseksual, dan perjudian; dan (d) birokrasi berupa penyalahgunaan kekuasaan, pemalsuan identitas dan pungutan liar. Kedua, novel Negeri di Ujung Tanduk mengandung nilai moral yaitu: (1) nilai moral individu (kejujuran, ketanggungjawaban, kemandirian, keberanian, kerendahhatian, serta realistik dan kritis); (2) nilai moral sosial mengenai cinta kasih dan peduli sosial; dan (3) nilai moral religius berupa bersyukur, berdoa, dan berbakti pada orang tua.

\section{DAFTAR PUSTAKA}

Bates, V. C. (2016). Introduction: Reaffirming Critical Theory for Social Justice in Music Education. Action, Criticism \& Theory for Music Education, 15(5), 1-5.

Esten, M. (2013). Kesusastraan (Pengantar Teori Sejarah). Bandung: Angkasa.

Endraswara, S. (2011). Metodologi Penelitian Sastra (Epistemologi, Model, Teori, dan Aplikasi, Edisi Revisi). Yogyakarta: CAPS.

Faruk. (2014). Pengantar Sosiologi Sastra. Yogyakarta: Pustaka Pelajar.

Jusriani. (2015). Konflik Tokoh dalam Novel Rindu Karya Tere Liye (Tinjauan Psikologi Sastra. Jurnal Humanika, 15(3), 1-15.

Liye, T. (2016). Negeri di Ujung Tanduk. Jakarta: PT Gramedia Pustaka Utama.

Mulyaningsih, I. (2015). Kajian Feminis Pada Novel "Ronggeng Dukuh Paruk" dan "Perempuan Berkalung Surban". Indonesian Language Education and Literature, 1(1), 107 - 119. DOI: http://dx.doi.org/10.24235/ileal.v1i1.75. 


$$
\begin{gathered}
\text { Indonesian Language Education and Literature } \\
\text { e-ISSN: } 2502-2261 \\
\text { http://www.syekhnurjati.ac.id/jurnal/index.php/jeill/ } \\
\text { Vol. 4, No. 1, Desember 2018, } 11-21
\end{gathered}
$$

Nurgiyantoro, B. (2013). Teori Pengkajian Fiksi. Yogyakarta: Gadjah Mada University Press.

Ratna, N. K. (2009). Teori, Metode, dan Teknik Penelitian Sastra. Yogyakarta: Pustaka Pelajar.

Semi, M. A. (2012). Metode Penelitian Sastra. Bandung: Angkasa.

Soekanto, S. (2013). Sosiologi Suatu Pengantar. Jakarta: Rajawali Pers.

Suseno, F. M. (2010). Etika Dasar Masalah-Masalah Pokok Filsafat Moral. Yogyakarta: Kanisius.

Wellek, R., \& Warren, A. (2014). Teori Kasusastran. Jakarta: PT Gramedia Pustaka Utama.

Wibowo, A. (2013). Pendidikan Karakter Berbasis Sastra: Internalisasi Nilai-Nilai Karakter melalui Pengajaran Sastra. Yogyakarta: Pustaka Pelajar.

Wiyatmi. (2009). Pengantar Kajian Sastra. Yogyakarta: Pustaka Book Publisher. 